"Monitoring intensity, investment inefficiency and institutional shareholders: Evidence from JSE listed companies in South Africa"

\begin{tabular}{|c|c|c|}
\hline \multirow{3}{*}{ AUTHORS } & \multicolumn{2}{|l|}{ Oloyede Obagbuwa (iD) } \\
\hline & \multicolumn{2}{|l|}{ Farai Kwenda (iD) } \\
\hline & \multicolumn{2}{|l|}{ Gbenga Wilfred Akinola (D) } \\
\hline ARTICLE INFO & \multicolumn{2}{|c|}{$\begin{array}{l}\text { Oloyede Obagbuwa, Farai Kwenda and Gbenga Wilfred Akinola (2021). } \\
\text { Monitoring intensity, investment inefficiency and institutional shareholders: } \\
\text { Evidence from JSE listed companies in South Africa. Investment Management } \\
\text { and Financial Innovations, 18(3), 1-15. doi:10.21511/imfi.18(3).2021.01 }\end{array}$} \\
\hline DOI & \multicolumn{2}{|c|}{ http://dx.doi.org/10.21511/imfi.18(3).2021.01 } \\
\hline RELEASED ON & \multicolumn{2}{|l|}{ Friday, 09 July 2021} \\
\hline RECEIVED ON & \multicolumn{2}{|l|}{ Saturday, 06 March 2021} \\
\hline ACCEPTED ON & \multicolumn{2}{|l|}{ Wednesday, 09 June 2021} \\
\hline & \multicolumn{2}{|l|}{$(\mathrm{cc}) \mathrm{EY}_{\mathrm{EY}}$} \\
\hline LICENSE & \multicolumn{2}{|c|}{$\begin{array}{l}\text { This work is licensed under a Creative Commons Attribution } 4.0 \text { International } \\
\text { License }\end{array}$} \\
\hline JOURNAL & \multicolumn{2}{|c|}{ "Investment Management and Financial Innovations" } \\
\hline ISSN PRINT & \multicolumn{2}{|l|}{$1810-4967$} \\
\hline ISSN ONLINE & \multicolumn{2}{|l|}{$1812-9358$} \\
\hline PUBLISHER & \multicolumn{2}{|c|}{ LLC "Consulting Publishing Company "Business Perspectives" } \\
\hline FOUNDER & \multicolumn{2}{|c|}{ LLC “Consulting Publishing Company "Business Perspectives" } \\
\hline \multirow[b]{2}{*}{ NUMBER OF REFERENCES } & & $\begin{array}{l}= \pm: \\
= \pm=-\end{array}$ \\
\hline & NUMBER OF FIGURES & NUMBER OF TABLES \\
\hline 68 & 1 & 3 \\
\hline
\end{tabular}

(c) The author(s) 2021. This publication is an open access article. 


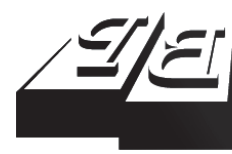

BUSINESS PERSPECTIVES

(O)

LLC "CPC "Business Perspectives" Hryhorii Skovoroda lane, 10, Sumy, 40022, Ukraine www.businessperspectives.org

Received on: $6^{\text {th }}$ of March, 2021 Accepted on: $9^{\text {th }}$ of June, 2021 Published on: $9^{\text {th }}$ of July, 2021

(C) Oloyede Obagbuwa, Farai Kwenda, Gbenga Wilfred Akinola, 2021

Oloyede Obagbuwa, Ph.D. Student, School of Accounting, Law and Management Faculty, Economics and Finance Department, University of KwaZulu-Natal, South Africa. (Corresponding author)

Farai Kwenda, Ph.D Associate Professor, School of Accounting, Law and Management Faculty, Economics and Finance Department, University of KwaZulu-Natal, South Africa.

Gbenga Wilfred Akinola, Ph.D., Dr., School of Accounting, Law and Management Faculty, Economics and Finance Department, University of KwaZulu-Natal, South Africa.
Oloyede Obagbuwa (South Africa), Farai Kwenda (South Africa), Gbenga Wilfred Akinola (South Africa)

\section{MONITORING INTENSITY, INVESTMENT INEFFICIENCY AND INSTITUTIONAL SHAREHOLDERS: EVIDENCE FROM JSE LISTED COMPANIES IN SOUTH AFRICA}

\begin{abstract}
This study investigates how variation in monitoring intensity affects the efficiency of firms' investment decisions in an emerging market in South Africa. The study hypothesis argues that the distraction of institutional shareholders has a statistically significant positive effect on corporate investment inefficiency. Using a more robust Generalized Method of Moments (Sys GMM) estimation approach to analyze data collected for firms listed at the Johannesburg Stock Exchange (JSE) for the period 2004-2019, the results showed that the distraction of institutional shareholders has a positive and statistically significant impact on investment inefficiency. That is, when the attention of institutional shareholders is shifted, the intensity of their monitoring drops, and the executive is involved in investment decisions that are not profitable. This insight has an implication for stakeholders and the value-creating corporate governance mechanism. The study concludes that institutional shareholders must always sustain their monitoring intensity to ensure that corporate decisions are consistent with the firm's value.
\end{abstract}

Keywords

institutional shareholders, investment inefficiency, monitoring intensity, system GMM, distraction measure, South Africa

JEL Classification G31, G34

\section{INTRODUCTION}

The involvement of institutional shareholders in corporate finance has become a crucial issue that is open to comprehensive research in corporate finance literature. These are large investors who invest on behalf of their members. They include the followings: superannuation and pension funds, life and non-life insurance companies, investment and unit trusts, financial institutions such as banks and finance companies, credit co-operatives, building societies, and investment companies (Koh, 2003; Survé, 2009). They are essential in the capital market due to their large holding of shares. The market value of their investment in the United States, British, and South African stocks is vast and significant (Bhikha, 2014; Blume \& Keim, 2012; Thomas, 2017; Ward et al., 2017). $80 \%$ of the US stock market's equity market is held by institutional investors (Intractive, 2017); institutional investors in FTSE 100 in the UK account for 62\% of total ownership (Segerstrom, 2020). Institutional shareholders constitute the majority of investors on the Johannesburg Stock Exchange (JSE) (Zhang, 2016), and they mostly include provident and pension funds, insurance companies, and collective investment schemes(CIS) (Nhlapo \& Gumata, 2011; Sibanda \& Holden, 2014). The size and significance of institutional shareholders have grown over time. This category of investors accounts for about 
$60-80 \%$ of South African asset manager records (Bhikha, 2014). The assets under management (AUM) had grown from USD 168.9 billion in December 2018 to USD 173.5 billion in November 2019 (Refinitiv, 2019). According to Gompers and Metrick (2001), institutional shareholders' continuous growth over forty years ago had ranked them as the most significant public firms' shareholders. Therefore, compared to individual shareholders, they have the incentives to monitor corporate decisions and ensure those decisions improve firms' value (Jabeen \& Ali, 2017; L. C. Stein \& Zhao, 2016). Because of the agency problem, corporate executives can make decisions that are of personal interest, but this conflict of interest can be controlled by effective monitoring through institutional shareholders (Bharath et al., 2013; Cheung et al., 2021; Edmans \& Manso, 2010; Jabeen \& Ali, 2017). However, the recent accounting scandals in South Africa, Steinhoff international scandal 2017, Tongaat Hulett scandal 2018, VBS Bank Scandal 2018, EOH Holdings scandal 2018, and Sasol LCCP scandal 2019 generate a debate on the effectiveness of institutional shareholder's monitoring role in JSE listed firms. It is expected that the growth of institutional shareholders vis-a-vis the volume of assets under management they controlled will guarantee effective monitoring of corporate decisions to ensure firm performance and growth. This seems not the case. Why is institutional shareholders' monitoring not effective enough to prevent the recent accounting scandals in firms listed on JSE? Will it be that they do not have all the time to monitor their investment? Otherwise, are they distracted? Since distraction had been identified by Kempf et al. Spalt (2017) as a constraint to effective monitoring, this study intends to enhance the understanding of the effects of institutional shareholders' monitoring intensity on corporate decisions - inefficient investment. The paper contributes to the literature by relating shareholders' distraction to South African firms' investment inefficient decisions. The study focused on emerging markets as the research so far focused on companies operating in developed economies. The managerial market in South Africa is still growing. This study will provide insight into how best to strengthen corporate governance to create a firm's value. Moreover, the study used a generalized method of moments (GMM), a dynamic estimator that control for cross-sectional dependence, heteroscedasticity, and serial correlation contrary to the application of only static models (ordinary least square (OLS), fixed effects, and random effects), which is incapable of resolving heterogeneity issues. To the best of the authors' knowledge, earlier related studies have entirely relied on static models.

This study used System GMM to analyze data collected from JSE listed firms; the analysis results indicated that institutional shareholders' monitoring intensity could be relaxed by distraction, thereby creating an opportunity for executives to invest wrongly to satisfy their interest. This finding is congruous with agency theory and extant literature on shareholders' distraction. For instance, Cheung et al. (2021), Garel et al. (2018), and Kempf et al. (2017) found that when monitoring intensity is reduced, managers engaged in value-destroying acquisitions that lower cash holdings, manipulate earnings, and increase the opportunity of receiving a lucky grant respectively.

\section{LITERATURE REVIEW}

\subsection{Institutional shareholders' monitoring and limited attention}

Standard economic models conjecture that shareholders use every information available to make prudent decisions. Nevertheless, psychology and behavioral finance literature assert that shareholders are contingent upon intellective restraints and emotional tendencies. The central intellectual-processing capacity of the human brain is limited. The volume of information appropriate for the firm's valuation is immense, and the time and intellectual resources needed to handle such information are substantial. Therefore, shareholders usually fail to integrate every appropriate information because of limited attention (Wang, 2017). This limited attention does not apply to individual shareholders alone but also to institutional shareholders. It was documented by Abarbanell and Bushee (1998) that analysts could not efficiently use available information in the financial ratios. Likewise, the analyst failed to discount discretional accruals of the firm's new issue sufficiently (Teoh \& Wong, 2015). Furthermore, Hirst and 
Hopkins (1998) provided empirical evidence that a professional analyst usually fails to recollect and react appropriately to information in detailed financial disclosures.

The survey conducted by the Investor Responsibility Research Center Institute IRRC (2011) revealed that institutional shareholders have limited attention. They document a direct connection between restriction to institutional shareholders' attention and monitoring of corporate decisions. They stated that "three-fourths of the institutional shareholders submit that time is the most usual barrier to engagement with the corporations, while staff plan ranks second." So, institutional shareholders do not equally monitor firms they invested in with the same enthusiasm. The implication of this is that institutional shareholders may become 'distracted' at a particular time. Although 'distracted', they provide below the optimal control level (Kempf et al., 2017).

Since the determinants of investor attention are not known, measuring shareholders' attention becomes problematic. To sidestep this challenge, various empirical proxies have been suggested to secure shareholders' attention. These proxies have produced many exciting and keen findings regarding stock price movement around important corporate information events such as earnings announcements, analyst recommendations, prominent attention-grabbing events, etc. (Wang, 2017). A typical empirical proxy relating to shareholders' attention is firm size. More prominent firms are generally focused upon by shareholders for several reasons. For example, they have more analyst coverage; more significant firms have more news media coverage than smaller firms. However, because firm size is also being used as a proxy for other variables like information asymmetry, using it as a proxy for shareholders' attention makes it a noisy measure. Additionally, even though the firm size and analyst coverage are proxies for the volume of the available information in the public domain, the measure becomes indirect because it is difficult to determine the extent to which the shareholder will utilise the information (Wang, 2017).

In this regard, researchers have suggested several optional proxies for institutional shareholder's attention or inattention. Dellavigna and Pollet
(2009) documented that since shareholders are distracted from stock valuation duties on Fridays, they become less attentive to earnings announcements made on Fridays than non-Fridays. In line with this thought, they noted restrained reactions to the stock market on Friday earning announcements trailed by the strong stock market movement compared to an announcement on non-Friday. Francis et al. (1992) and Bagnoli et al. (2005) discovered less reaction to earnings announced within nontrading hours. Similarly, Hirshleifer et al. (2009) investigated many information overflows by numerous earning announcements per day. They discovered that the response to the day's announcement is smaller than the reaction after the announcement, which is better about several competitive announcements. However, the same day's earnings announcement from a different industry is a lot more distracting than industry-related announcements. Engelberg and Gao (2011) suggested that the Google search volume index offers a better direct measure for shareholders' attention. They discussed that the large number of requests for stocks on Google is an indication that many shareholders pay attention to and find information about the particular stock. They recorded a positive relationship between changes in the volume of search and shareholders' trading. Besides, they documented that an increase in shareholder's attention is related to stock returns of the first-day IPO.

Considering the optional empirical surrogates, trading volume is much more notable and broadly used. The perception is unambiguous. Shareholders hardly trade in stocks they pay less attention to. Whereas the likelihood of stock trade they pay greater attention to is high. That is to say, attention is well correlated with the volume of trade. Evidence from the literature has lent credence to the linkage between shareholder's attention and trade volume. Boone and White (2015) demonstrated that trade volume, especially in large stocks, attracts shareholders' attention. Chordia (2000) showed that, despite controlling for firm size, high volume stocks respond quickly to market returns information compared to low volume stocks. This indicates that trading volume reflects information regarding shareholder attention over and above firm size. Gervais et al. (2001) proposed that stock visibility is induced by the high trad- 
ing volume, which attracts shareholders. Barber and Odean (2008) used an abnormal daily trading volume of stock to reflect the stock's change in shareholder's attention. In addition to unusual trading volume, the authors also suggested news and extreme returns as proxies for attention. Hou et al. (2009) discovered that earnings thrust profits are higher within the low volume stocks. This is attributable to less shareholder's attention and intense reaction to earnings announcements in the stock market. Kempf et al. (2017) established that an institutional shareholder's effective monitoring could be hampered when distracted by external shock affecting their investment in unrelated firms.

\subsection{The role of an institutional shareholder in corporate governance in South Africa}

King's report affirmed the important role of an institutional shareholder in corporate governance, best suited to South Africa. King's report on corporate governance is the detailed booklet of guidelines that spelt out companies' governance structures and operations in South Africa. The King Committee on corporate governance issues it. The Institute of Directors in South Africa (IoDSA) possesses the King's copyright and corporate governance code. Companies listed on the Johannesburg Stock Exchange (JSE) must comply with King's report requirements. King reports issued so far were King I in 1994, King II in 2002, King III in 2009, and King IV in 2016.

About King II, institutional shareholders in South Africa have shown less concern in actively participating in a shareholder's meeting. Hence, they were advised to consider the National Association of Pension Funds' action and the Association of British Insurers in the United Kingdom in creating a standard in line with good corporate governance that companies must follow. The report further stated that the lack of shareholder activism in South Africa weakens managerial compliance. The institutional shareholder maintained a passive nature despite apparent occurrences of companies' inadequate and unsuitable corporate governance practices. However, in recent times, a moderate level of shareholder activism is noticed. For instance, the influence of an institutional sharehold- er on the former co-operative OTK (now Afgri) in adopting a new restructuring strategy, the Camparex (now known as Business Connexion), the reconstituted boards of Kersaf, the rejection of the delisting of plans of Energy Africa and Mutual \& Federal, as well as the intervention of Public Investment Corporation (PIC) in the payment of executive remuneration for both companies of Dorbyl and Aveng (Survé, 2009)

Regarding King III, in 2011, the Code for Responsible Investment in South Africa (CRISA) was released. This code proffers guides institutional shareholder ways of executing their investment and using their rights to improve governance. After CRISA was released, South Africa became the second country after the United Kingdom to motivate institutional shareholders to incorporate Environmental, Social, and Governance (ESG) contemplations into their investment preferences. In the King IV draft report, critical attention was paid to institutional shareholder's responsibilities. While the earlier King reports on the board of directors' positions as a contact point of corporate governance, the King IV report extends the implementation to cover institutional shareholder responsibilities referred to as institutional shareholder fiduciary duty. From the 17 principles of King's report beginning from 75 in King III, one relates explicitly to institutional shareholders. This shows their investee companies' gains when they are alive to their corporate monitoring activities (Harber, 2017). As stated in King IV principle 17 , an institutional shareholder must ensure that profitable investment is initiated and practised by their investee companies to strengthen good governance and value creation (Harber, 2017; IoDSA, 2016). They should pursue and enforce high-yielding investments that guarantee long-term and lasting returns. Their actions and inaction will either strengthen or weaken good governance (IoDSA, 2016). Also, Zhang (2016) reiterated the responsibility of institutional shareholders to comply with their fiduciary duties by incorporating ESG contemplations and ensuring investee firms' continuing development (Zhang, 2016). Overall, however, it seems that institutional shareholders are still inactive with regard to their responsibilities. King's reports have highlighted the limited role institutional shareholders have played regarding corporate governance developments and expressed a 
clear demand for more active shareholder monitoring engagement.

\subsection{Investment efficiency}

A firm's investment decision is driven by investment opportunities that always lead to its growth due to the positive net present value (NPV) estimated. This investment decision is expected to be maintained until the minimum benefit is reached (Benlemlih \& Bitar, 2018; Hayashi, 1982; Modigliani \& Miller, 1958). In reality, firms face financial difficulties that prevent managers from executing all projects with positive NPV (Hubbard, 1997). Extant literature discovered that capital market contentions could make firms deviate from optimal investment (Chen et al., 2017), eventually leading to either underinvestment or overinvestment. This leads to underinvestment when, due to high-cost funding capital, all projects with a positive NPV are dropped (Biddle et al., 2009).

On the other hand, this results in overinvestment when managers deliberately select destructive projects and misappropriate their resources. J. C. Stein (2003) stated there was a range of market contentions and other forces of distortions that prevent the optimum level of investment. However, studies highlighted two major types critical to investment efficiency, namely agency problem and information asymmetry (Benlemlih \& Bitar, 2018).

Myers and Majluf (1984) reiterate its effects on the cost of capital and the selection of projects regarding information asymmetry. When managers are aware that stocks are overvalued, they tend to issue new ones. But, when shareholders have this information, they discount the new issuance of stocks. However, managers may decide not to raise capital at a discounted price even when it means abandoning profitable investment opportunities, ultimately leading to underinvestment. Besides information asymmetry, Chen et al. (2017) emphasized the agency problem perspective. That managers are self-serving and always tend to select investment opportunities that enhance their benefits to the detriment of shareholders (Jensen \& Meckling, 1976). So, the agency problem increases investment inefficiency. As Jensen (1986) predicted, managers with illusions of grandeur will always overinvest with available free cash flow. This becomes intense when the monitoring intensity of the shareholders is relaxed. Other extant literature equally affirmed that the conflicting interest between shareholders and managers might prevent companies from investing efficiently (Ward et al., 2017). Jensen and Meckling (1976), Richardson (2006), and Shleifer and Vishny (1997) document that the agency problem leads to over-investment, while Aghion et al. (2013), Bertrand and Mullainathan (2003), and Porter (1992) confirm that it leads to under-investment. Furthermore, Titman et al. (2004) and Cai and Zhang (2011) stated that high investment inefficiency reduced firm value. Therefore, having an insight into the impact of institutional monitoring on companies' investment decisions become imperatives.

\section{DATA AND METHODOLOGY}

\subsection{Data sources}

Data on institutional shareholders' shareholding and other variables were sourced from S\&P Capital IQ. The data on institutional shareholders were used in computing the distraction measure, which is the variable of interest. The sample period is from 2004 to 2019, and all listed companies in JSE were considered subject to data availability. For details on variables see Appendix A.

\subsection{Measuring institutional shareholder distraction}

Following Kempf et al. (2017) and Liu et al. (2017), this study will construct a company-level proxy for total institutional shareholder distraction. This shows how many institutional shareholders in a given firm $_{f}$ are distracted in a given period. This distraction measure is denoted $D t$, and it is defined to assign higher values to more distracted shareholders. Concerning the alternative hypothesis, a higher $D t$ suggests a temporary loosening of institutional shareholders' monitoring intensity.

The thinking behind $D t$ is that a given shareholder $i$ in a given firm $_{f}$ is most probably distracted in the event of an attention-grabbing occurrence in another industry significant in the investor $i$-portfolio. Therefore, this study will first calculate a shareholder-level distraction score and, 


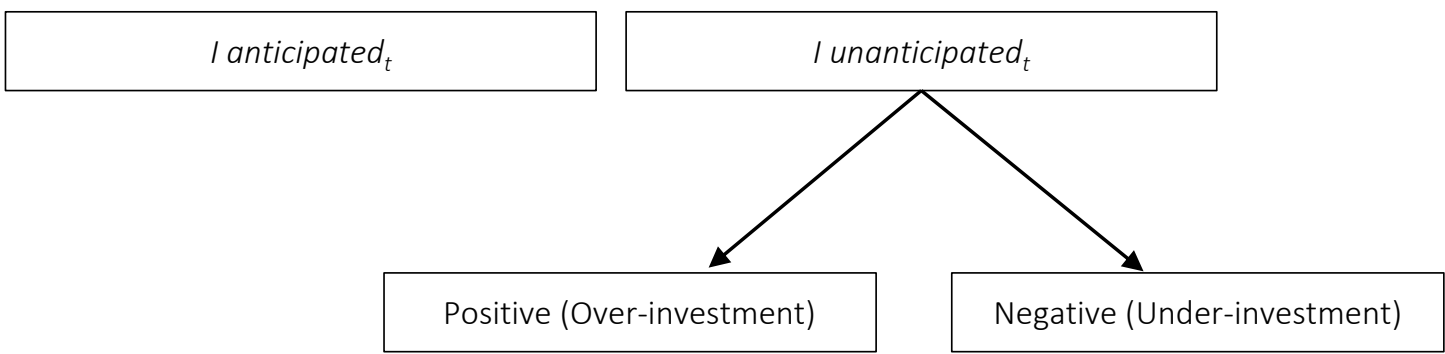

Figure 1. Breakdown of investment expenditure

after that, sum it across all investors in the firm. Precisely, $D t$ for each firm $_{f}$ at period $t$ is modelled as:

$$
D t_{f t}=\sum_{i \varepsilon f t-1} \sum_{I N D \neq I N D f} w_{i f t-1} X w_{i t-1}^{I N D} X \cdot I S_{t}^{I N D}
$$

where $f_{t-1}$ connotes institutional shareholders' set of firms at the end of period $t-1, I N D$ connotes JSE 11 industry classification, and $I N D_{f}$ connotes firm $_{f}$ industry sector, $I S_{t}^{I N D}$ indicates if there is a distraction in industry $I N D$, and $w_{i t-1}^{I N D}$ connotes the weight of the industry sector IND in the institutional shareholder i's portfolio. The weight $w_{i, f, t-1}$ estimates the significance of investor $i$ in firm $_{f}$ at the end of period $t-1$ By intuition, investor $i$ is significant if 1) firm f weight $^{2}$ in investor $i$ 's portfolio is higher, and 2) if the proportion of firm $_{f}$ shares owned by investor $i$ is large. Hence, $w_{i f t-1}$ is estimated as:

$$
W_{i f t-1}=\frac{Q P F \text { weight }_{i f t-1}+Q P e r O w n_{i f t-1}}{\sum_{i \varepsilon f t-1}\left(Q P F \text { weight }_{i f t-1}+Q P e r O w n_{i f t-1}\right)},
$$

where PFweight ${ }_{i f t-1}$ is the firm $_{f^{\prime} s}$ market value weight in the investor $i^{\prime}$ s portfolio, while $\operatorname{PerOwn}_{i f t-1}$ is the proportion ownership the investor ${ }_{i}$ has in firm $_{f}$. To avoid outliers, firms in investor $_{i^{\prime}}$ portfolio in the period $t-1$ are classified into quintiles based on $P F$ weight $t_{i f t-1}$ and this connotes QPFweight $t_{i f t-1}$. Likewise, QPerOwn $n_{i f t-1}$ represents the quintile value of

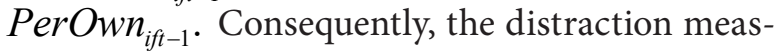
ure delivers more weight to institutional shareholders that possess somewhat more shares in firm $_{i}$. This is because managers take good care of their significant shareholders as they believe they have an incentive to monitor (Edmans \&
Holderness, 2017). Moreover, it allocates more weight to institutional shareholders that firm $_{i}$ takes a higher proportion in their portfolio. This is due to the fact that institutional shareholders pay more attention to the most significant position in their portfolio.

\subsection{Measuring investment inefficiency}

Inefficient investment is defined as the digression from the investment level capable of being anticipated by a company-specific investment model (Ward et al., 2017).

Richardson (2006) studied the link between free cash flows and the extent of overinvestment at the company level. Employing the framework of accounting, he formulates investment efficiency measures by breaking down the total investment. He separates the total investment $\left(I_{\text {Total }, t}\right)$ into two parts such as the needed investment cost to sustain asset in place $\left(I_{\text {Maintain, },}\right)$ and investment cost on new ventures $\left(I_{\text {New }, t}\right)$. Further, $I_{\text {New }, t}$ is separated into anticipated investment and unanticipated investment. The unanticipated investment measures inefficient investment, and it can be negative or positive. The negative value is the under-investment, while the positive value is the over-investment.

$$
I_{\text {Total }, t}=I_{\text {Maintain }, t}+I_{\text {New }, t} .
$$

Following Richardson (2006), Stoughton et al. (2017), and Gao and $\mathrm{Yu}$ (2020), the expectation model below was used to estimate the anticipated new investment, and the residuals were used as a proxy for the company-specific unanticipated (inefficient) investment: 


$$
\begin{aligned}
& \text { INew }_{i t}=\alpha+\beta_{1} \frac{v}{p_{i t-1}}+\beta_{2} \text { Leverage }_{i t-1}+ \\
& +\beta_{3} \text { Cash }_{i t-1}+\beta_{4} \text { Age }_{i t-1}+\beta_{5} \text { Size }_{i t-1}+ \\
& +\beta_{6} \operatorname{Re} \text { turn }_{i t-1}+\beta_{7} \text { INew }_{i t-1}+\delta_{i}+\mu_{t}+\varepsilon_{i t}
\end{aligned}
$$

where $I N e w_{i t}$ is the investment expenditure on new projects of company in year $r_{t}$ and INew $_{i t}=$ ITotal $_{i t}-$ IMaintenance $_{i t}$. ITotal It $_{i t}$ is the whole investment, while Maintenance $_{i t}$ is the investment cost of maintaining the assets. INew is broken down into anticipated investment and unanticipated investment. Unanticipated investment is the measure of inefficient investment.

The extant literature on economics and finance shows that investment in a firm is influenced by opportunities for growth, financial restraints, and other firm peculiarities (Gao \& Yu, 2020; Hubbard, 1997; Yin, 2018). Firm growth opportunities are calculated by $V / P$, computed as the ratio of firm value to the firm market value of equity. $\mathrm{V}$ is the asset in place derived from the income model; $P$ is the firm market value (Ohlson, 1995; Yin, 2018). Factors that influence investment decisions have been incorporated as control variables. Financial restraints are measured by Cash and Leverage. It is expected that INew will be negatively associated with Leverage and positively associated with Cash. Other firm peculiarities as contained in equation 3 include a natural log of a company's total assets (Size), the firm age (Age), aggregate returns on the stock over the previous year (Return), and lag of new investment $I_{\text {Newit-1 }}$ to appropriate other firm attributes that impact investment, firm fixed effects $\left(\delta_{i}\right)$, as well as year fixed effects $\left(\mu_{t}\right)$ are incorporated to control for unobserved company peculiarities and the trend in stock market, respectively. $\varepsilon_{i t}$ is the error term.

Income model for the asset in place:

$$
(1-\alpha r) B V+\alpha(1+r) X-\alpha r d
$$

where

$$
\alpha=W / 1+r-W, r=12 \%, W=0.62, B V
$$

is the book value of equity, $d$ is the annual dividend, and $X$ is the operating income (Ohlson, 1995; Richardson, 2006; Ward et al., 2017).

\subsection{The effect of shareholder distraction on inefficient investment}

Limited attention due to shareholder distraction has been proven from extant literature (Cheung et al., 2021; Garel et al., 2018; Kempf et al., 2017; Ward et al., 2017), which limits monitoring responsibility of an institutional shareholder and enables executives to invest inefficiently. To test hypothesis one, the baseline regression model stated below is adopted to examine the impact of shareholder distraction on inefficient investment decisions:

$$
\begin{aligned}
& \text { Inefinvest }_{i t}=\alpha_{0}+\delta \text { Inefinvest }_{i t-1}+ \\
& +\beta D t_{f t}+y X_{i t}+\mu_{i}+W_{t}+\varepsilon_{i t},
\end{aligned}
$$

where inefficient investment $\left(\right.$ Inefinvest $_{i t}$ ) is a proxy by the residual of equation (3.4). Dt $t_{f t}$ is the institutional shareholder distraction measure; $X$ is the vector of other explanatory variables, e.g. as motivated by Stoughton et al. (2017) and Ward et al. (2017) are MTB, Tangibility, Size, Age, Leverage, and Cash; $\mu$ is the unobserved firm-specific fixed effect; $W$ is the time trend; $\delta, \beta$ and $y$ are parameters; $i$ is the number of firms $(=1, \ldots, N), t$ is the numbers of years $(=1, \ldots, T)$, and $\varepsilon$ is the error term.

\subsection{Estimating technique}

\subsubsection{GMM model specifications}

This study explored the dynamic panel data approach called the generalized method of moments (GMM) proposed by Arellano and Bond (1991). It generates a model that enhances the efficiency of the estimator. This equation modifies the fixed effect equation with the incorporation of instrumental variables. GMM can either be estimated using Difference GMM or System GMM.

Difference GMM: It was proposed by Arellano and Bond (1991). It corrects endogeneity by transforming independent variables through differencing. It also removes the fixed effect. However, the first differencing transformation has a weakness as it subtracts the previous observation from the contemporary one, thereby magnifying gaps in an unbalanced panel. 
The difference GMM initial model is stated below:

$$
y_{i t}=\varphi y_{i t-1}+\beta X_{i t}+\left(n_{i}+\varepsilon_{i t}\right),
$$

where $y_{i t}$ represents a firms' investment inefficiency; $\beta$ for $i=1,2$ and estimate parameters for independent variables; $\varphi$ is the coefficient of lagged dependent variable; $X_{i t}$ is the exogenous independent variables, $n_{i}$ connotes the firm-specific effect, and $\varepsilon_{i t}$ is the error term.

Transformed model:

$$
\Delta y_{i t}=\varphi \Delta y_{i t-1}+\beta \Delta X_{i t}+\Delta \varepsilon_{i t}
$$

When the regressors are transformed through first differencing, the fixed effect is removed, since it did not vary over time, but endogeneity remains. From equation (8), the model becomes

$$
\Delta \mu_{i t}=\Delta n_{i}+\Delta \varepsilon_{i t}
$$

or

$$
\begin{aligned}
& \mu_{i t}-\mu_{i t-1}=\left(n_{i}-n_{i-1}\right)+ \\
& +\left(\varepsilon_{i t}-\varepsilon_{i t-1}\right)=\varepsilon_{i t}+\varepsilon_{i t-1} .
\end{aligned}
$$

The unobserved fixed effects no longer enter the equation as they are, by assumption, constant between periods. The first-differenced lagged dependent variable is instrumented with its past levels and now changes in the dependent variable as assumed to be represented by equation (8). So, equation (8) still shows that there is endogeneity in the model due to the lagged dependent variable $\Delta y_{i t-1}$ being correlated with the error term $\Delta \varepsilon_{i t}$.

System GMM: It proposed by Arellano and Bover (1995) and Blundell and Bond (1998). It corrects endogeneity by introducing more instruments to improve efficiency significantly. Also, it transforms the instruments to make them uncorrelated (exogenous) with fixed effects. Moreover, it builds a system of two equations: the original equation and the transformed one. It used orthogonal deviations. That means rather than deducting the previous observation from the contemporaneous one, it deducts the average of all future available observation of a variable. Regardless of the data gaps, they can be estimated for all observations apart from the last for each individual, thereby reducing data loss.
For the system GMM model, the initial model under difference GMM equation (6) refers. The equation is assumed to be a random walk model, and the dependent variable $(y)$ is persistent. In this case, applying the difference GMM estimator will yield both bias and an inefficient estimate of $\varphi$ in limited samples, and this is especially keen when $T$ is short. According to Blundell and Bond (1998), the underperformance of difference GMM in these circumstances is due to poor instruments. Therefore, the system GMM is applicable for the reasons stated below.

One equation is stated in the form of levels with the first difference as instruments, and the second equation is expressed in the first difference with levels as instruments. This approach includes more significant numbers of moment conditions. Still, in the study by Arellano and Bond (1991), Monte Carlo evidence indicates that when $T$ is short, and the dependent variable is persistent, there are gains in accuracy, and small sample bias is minimized. Besides, when there are heteroscedasticity and serial correlation, a two-system GMM estimator should be used utilising a weighting matrix using residual from the first step. However, where there are limited samples, standard errors tend to be downward biased. In such a case, practitioners' usual approach is to use Windmeijer adjustment to correct for such small sample bias (Arellano \& Bond, 1991; Arellano \& Bover, 1995; Blundell \& Bond, 1998; Windmeijer, 2005).

To estimate the dynamic model of this study in nature and control for endogeneity, the GMM estimation method was adopted. Extant literature established that a dynamic panel model improves estimators' efficiency in a panel model (Arellano \& Bond, 1991). Oyedokun et al. (2009) stated that the combination of static specification of fixed effect model and autoregressive coefficients, the lagged value of the dependent variable, provides responses of both past and present shocks to the current value of the dependent variable. This specification method is referred to as GMM. The GMM eliminates temporal autocorrelation in the residual and averts running a spurious regression that may cause inconsistent estimators. The orthogonal conditions in the variance-covariance application control for correlation of errors, heteroscedasticity, simultaneity, and endogeneity issues (Antoniou et 
al., 2008; Vengesai, 2019). The GMM model that explains the link among firm investment inefficiency, distraction measure, and other regressors is specified below:

$$
\begin{aligned}
& \text { Inefinvest }_{i t}=\alpha_{0}+\text { SInefinvest }_{i t-1}+ \\
& +\beta_{1} D t_{f t}+\beta_{2} \text { MTB }_{i t}+\beta_{3} \text { Tangibility }_{i t}+ \\
& +\beta_{4} \text { Size }_{i t}+\beta_{5} \text { Age }_{i t}+\beta_{6} \text { Leverage }_{i t}+ \\
& +\beta_{7} \text { Cash }_{i t}+\mu_{i}+W_{t}+\varepsilon_{i t} .
\end{aligned}
$$

Subsequently, taking the first difference of equation (11), the following equation (12) will be obtained:

$$
\begin{aligned}
& \text { Inefinvest }_{i t}=\alpha_{0}+\Delta \text { SInefinvest }_{i t-1}+ \\
& +\Delta \beta_{1} \text { Dt }_{i t}+\Delta \beta_{2} \text { MTB }_{i t}+\Delta \beta_{3} \text { Tangibility }_{i t}+ \\
& +\Delta \beta_{4} \text { Size }_{i t}+\Delta \beta_{5} \text { Age }_{i t}+\Delta \beta_{6} \text { Leverage }_{i t}+ \\
& +\Delta \beta_{7} \text { Cash }_{i t}+\mu_{i}+W_{t}+\Delta \varphi_{i t} .
\end{aligned}
$$

To ensure that likely correlation between Inefinvest $_{i t-1}$ and $\varphi_{i t}$ is avoided, an instrumental variable $N^{\prime}$, which will not be correlated with the two, is achieved by matrix transcription of regressors. Equation (15) is multiplied by in vector form by $N^{\prime}$ and gives the two-step system GMM estimated equation:

$$
\begin{aligned}
& N^{\prime} \Delta \text { Inefinvest }_{i t}=\alpha_{0}+N^{\prime} \Delta \text { SInefinvest }_{i t-1}+ \\
& +N^{\prime} \Delta \beta_{1} \text { Dt }_{i t}+N^{\prime} \Delta \beta_{2} \text { MTB }_{i t}+ \\
& +N^{\prime} \Delta \beta_{3} \text { Tangibility }_{i t}+N^{\prime} \Delta \beta_{4} \text { Size }_{i t}+ \\
& +N^{\prime} \Delta \beta_{5} \text { Age }_{i t}+N^{\prime} \Delta \beta_{6} \text { Leverage }_{i t}+ \\
& +N^{\prime} \Delta \beta_{7} \text { Cash }_{i t}+\mu_{i}+W_{t}+N^{\prime} \Delta \varphi_{i t} .
\end{aligned}
$$

Table 1. Summary statistics

\section{RESULTS}

\subsection{Summary statistics}

Table 1 presents the sample's summary statistics regarding the impact of distraction measures on inefficient investment. The sample period is between 2004 and 2019. The summary statistics reported the mean, standard deviation, median, minimum, maximum, skewness, and kurtosis values across the panel data variables. The detailed definition of variables is provided in Appendix A.

The summary statistics showed that the distraction measure $(D t)$ has a minimal effect on inefficient investment. The mean value of $D t$ is 0.000795 , while the minimum and maximum values are -0.877 and 0.932 , respectively. The mean value is close to the minimum, indicating that the impact of distraction on the dependent variables is small. It confirms the alternative hypothesis that the distraction measure affects inefficient investment. Moreover, the standard deviation of 0.0816 reflects a low level of variability from the mean.

\begin{tabular}{|c|c|c|c|c|c|c|c|c|}
\hline \multirow{2}{*}{ Variables } & $(1)$ & $(2)$ & (3) & (4) & $(5)$ & (6) & $(7)$ & $(8)$ \\
\hline & $\mathbf{N}$ & sum & mean & sd & $\min$ & $\max$ & kurtosis & skewness \\
\hline Inefinvest & 2.248 & -0.0187 & $-8.31 e-06$ & 0.562 & -9.005 & 11.86 & 212.9 & 5.525 \\
\hline Leverage & 2.367 & 531.5 & 0.225 & 0.467 & 0 & 9.503 & 119.3 & 8.936 \\
\hline Cash & 2.368 & 394.0 & 0.166 & 0.647 & 0 & 20.82 & 646.9 & 23.71 \\
\hline Size & 2.367 & 19.789 & 8.360 & 2.418 & -2.042 & 16.73 & 2.975 & 0.00432 \\
\hline Tan & 2.368 & 855.1 & 0.361 & 1.179 & 0 & 30.94 & 349.3 & 16.54 \\
\hline Age & 2.448 & 2.557 & 1.044 & 0.381 & 0 & 1.602 & 4.736 & -1.560 \\
\hline MTB & 2.353 & 21.421 & 9.104 & 133.5 & -3.333 & 5.187 & 1.020 & 29.22 \\
\hline Distraction & 1.924 & 1.530 & 0.000795 & 0.0816 & -0.877 & 0.932 & 47.51 & 0.446 \\
\hline Number of id & 150 & 150 & 150 & 150 & 150 & 150 & 150 & 150 \\
\hline
\end{tabular}

\subsection{Correlation matrix analysis}

In the correlation analysis (see Table 2), the distraction measure $(\mathrm{Dt})$, the variable of interest, is positively correlated with inefficient investment and is statistically significant. This means that an increase in Dt will lead to a rise in investment inefficiency. All other independent variables displayed a positive association with the dependent variable, showing positive and negative relationships. Generally, the analysis indicates that there is no multicollinearity between the variables.

Source: Author's computation, 2021. 
Table 2. Pairwise correlation matrix analysis

\begin{tabular}{|c|c|c|c|c|c|c|c|c|}
\hline \multicolumn{9}{|c|}{ Source: Author's computation, 202} \\
\hline Variables & (1) & (2) & (3) & (4) & (5) & (6) & (7) & (8) \\
\hline (1) Inefinvest & 1.000 & & & & & & & \\
\hline (2) $D t$ & $0.090^{*}$ & 1.000 & & & & & & \\
\hline (3) Lev & 0.002 & 0.001 & 1.000 & & & & & \\
\hline (4) $\mathrm{CHR}$ & 0.006 & $0.065^{*}$ & $0.287 *$ & 1.000 & & & & \\
\hline (5) Size & 0.010 & 0.015 & -0.038 & $-0.108^{*}$ & 1.000 & & & \\
\hline (6) Tan & $0.490^{*}$ & $0.062^{*}$ & $0.592^{*}$ & $0.710^{*}$ & $-0.049^{*}$ & 1.000 & & \\
\hline (7) Age & 0.004 & 0.011 & -0.012 & -0.023 & $0.241^{*}$ & -0.028 & 1.000 & \\
\hline (8) MTB & 0.030 & -0.020 & $0.113^{*}$ & -0.011 & $-0.046^{*}$ & $0.050^{*}$ & -0.012 & 1.000 \\
\hline
\end{tabular}

Note: ${ }^{* * *} p<0.01, * * p<0.05$, and $* p<0.1$.

\subsection{Dynamic panel data analysis}

Investment patterns are dynamic; companies thrive on straightening their investment trends over time. Consequently, prior-year investment behavior affects current trends. Incorporating the lagged dependent variable helps measure the previous investment impact on the current investment levels and minimize autocorrelation from misspecification (Arellano \& Bond, 1991). A dynamic panel model vis-a-vis the estimating techniques mitigate against likely heterogeneity and endogeneity problems in the data sample. Over a while, investment dynamics are captured in the dynamic model, and partial adjustment instrument modeling is allowed (Baum et al., 2001; Vengesai, 2019). So, to determine the estimation's robustness, the study used dynamics panel data model techniques, system GMM. System GMM had been proved in the literature to produce an efficient estimate (Arellano \& Bover, 1995; Blundell \& Bond, 1998). It corrects endogeneity by introducing more instruments to improve efficiency significantly. According to Antoniou et al. (2008), the conventional estimation techniques that are the OLS, fixed, and random effects cannot control the dynamic biasness. Therefore, it is necessary to introduce stochastic variation into the model. System GMM had been confirmed as an appropriate estimation technique when there is serial correlation from idiosyncratic disturbances, heteroscedasticity, and endogenous regressors (Roodman, 2009).

\subsection{Two-step system GMM results}

Table 3 shows the regression results of the two-step system GMM. The dependent variable is Inefficient investment, while the independent variable of interest is the distraction measure (Dt). Other regressors include Lagged inefficiency, Leverage, Cash holding ratio, Size, Age, Tangibility, and Market to book ratio (MTB). The sample consists of 153 firms and years from 2004 to 2019.

Table 3. Impact of shareholder distraction on inefficient investment

Source: Author computation, 2021

\begin{tabular}{|c|c|}
\hline \multirow{3}{*}{ Variables } & (1) \\
\hline & Model \\
\hline & Two-step system GMM \\
\hline \multirow{2}{*}{ LInefinvest } & $-1.0833^{* * *}$ \\
\hline & $(0.0354)$ \\
\hline \multirow{2}{*}{ Dt } & $0.1674^{*}$ \\
\hline & $(0.0909)$ \\
\hline \multirow{2}{*}{ Leverage } & $-0.7214^{* * *}$ \\
\hline & $(0.1948)$ \\
\hline \multirow{2}{*}{ Cash Holding Ratio } & $-0.8114 * * *$ \\
\hline & $(0.1292)$ \\
\hline \multirow{2}{*}{ Size } & -0.0267 \\
\hline & $(0.1377)$ \\
\hline \multirow{2}{*}{ Age } & $-0.0973 * *$ \\
\hline & $(0.0463)$ \\
\hline \multirow{2}{*}{ Tangibility } & $0.7528^{* * *}$ \\
\hline & $(0.0835)$ \\
\hline \multirow{2}{*}{ MTB } & 0.0020 \\
\hline & $(0.0014)$ \\
\hline \multirow{2}{*}{ Constant } & $0.1519 * *$ \\
\hline & $(0.0674)$ \\
\hline Observations & 1,860 \\
\hline Number of id & 153 \\
\hline Year dummies & Yes \\
\hline Instruments/Groups & $45 / 153$ \\
\hline $\begin{array}{l}\text { Arellano-Bond } \mathrm{AR}(2) \\
p \text {-value }\end{array}$ & 0.364 \\
\hline Hansen statistics $p$-value & 0.410 \\
\hline$F$-Statistic/p-value & $94.79 / 0.000$ \\
\hline
\end{tabular}

Note: White heteroscedasticity-consistent standard errors are in parentheses; $* * * p<0.01, * * p<0.05$, and $* p<0.1$ are statistically significance at $1 \%, 5 \%$ and $10 \%$ levels, respectively. The Hansen statistics $p$-value of 0.410 indicates that the instruments are valid, while the Arellano-Bond $A R(2) p$-value of 0.364 showed no $2^{\text {nd }}$ order autocorrelation. The F-statistics with a $p$-value of 0.000 indicated that the regressors are jointly significant in explaining the dependent variable. 
The finding shows a positive relationship between a shareholder's distraction and inefficient investment and is statistically significant. The result indicates a positive coefficient of 0.1674 and is statistically significant at $10 \%$. This implies that a unit of a 0.1674 increase in a shareholder's distraction will lead to a 0.1674 increase in the level of inefficient investment. This confirms the assumption that institutional shareholders are subject to distraction due to extreme events in an unrelated industry in their portfolio, thereby weakening control over corporate monitoring. The executive takes advantage of that and engages in unprofitable investments that jeopardize the firm's value to shareholders' detriment. The results are similar to the study by Ward et al. (2017), where they link a less motivated institutional investor to investment inefficiency and obtained positive coefficients. The authors found out that institutional shareholders' higher motivated monitoring reduces over-investment and under-investment. Furthermore, the firm's tangible assets have a positive effect on investment inefficiency. The result can be the indiscriminate asset acquisition for personal interest. Other control variables, such as leverage, cash holding ratio, size, and age, reported negative effects on investment inefficiencies.

\section{DISCUSSION}

An important factor for considering a corporate investment ought to be the optimization of the firm's value. Corporate decisions related to investment should be effective and efficient to guarantee future returns to stakeholders, including the institutional shareholders. However, according to agency theory, the potential conflicts of interest between the shareholders and managers influences inefficient managerial decisions that lead to inefficient investments (Imegi and Nwokoye, 2015)

The unproductive managerial decision prompted by a manager's opportunistic behaviour can be checked by adequate monitoring of the manager's corporate activities by the institutional shareholders. In other words, loosening the monitoring intensity of institutional shareholders exacerbate manager's free riders' tendencies where investment decisions seek to satisfy the personal interest. The study findings corroborate this fact. Distraction measure, which is a proxy for loosening monitoring intensity, show a positive and significant impact on inefficient investment. Furthermore, the results reflect one of the factors (uncontrolled acquisition spree) that contributed to the accounting scandal rocking Steinhoff International in South Africa.

\section{CONCLUSION}

The paper investigated the relationship between institutional shareholders' distraction and corporate investment inefficiency. The study's hypothesis shows that institutional shareholders' distraction is statistically significant and positively affects investment inefficiency. The more robust dynamic panel data estimation of system GMM is employed in the analysis to achieve the study's objectives. The study provides evidence from the findings: (1) Institutional shareholders' distraction significantly affects corporate investment inefficiency; (2) The firm asset tangibility significantly affects investment inefficiency. The paper's findings explain the recent accounting scandals in South Africa, where ineffective corporate governance was blamed for its cause. The ineffective corporate governance brought about by insufficient institutional shareholders' monitoring gives rise to opportunistic executive behavior, leading to financial scandals. Besides, although the effects of limited attention on institutional monitoring intensity had been explored in literature, this study, however, contributes to the extant literature by providing an understanding of how executives in an emerging economy respond to shifts in institutional shareholders' monitoring intensity, which, to the best of authors' knowledge is the first-hand evidence in South Africa. This understanding will spur action that will strengthen corporate governance in the face of future accounting scandals. Overall, the findings indicate that having insight into how corporate executives react to temporally loosening monitoring intensity can considerably enhance corporate governance perception of value creation in companies. 


\section{AUTHOR CONTRIBUTIONS}

Conceptualization: Oloyede Obagbuwa.

Data curation: Oloyede Obagbuwa.

Formal analysis: Oloyede Obagbuwa, Gbenga Wilfred Akinola.

Investigation: Oloyede Obagbuwa.

Methodology: Oloyede Obagbuwa, Gbenga Wilfred Akinola.

Project administration: Farai Kwenda.

Resources: Farai Kwenda.

Supervision: Farai Kwenda, Gbenga Wilfred Akinola.

Writing - original draft: Oloyede Obagbuwa.

Writing - review \& editing: Farai Kwenda, Gbenga Wilfred Akinola.

\section{REFERENCES}

1. Abarbanell, J. S., \& Bushee, B. J. (1998). Abnormal returns to a fundamental analysis strategy. The Accounting Review, 73(1), 1945. Retrieved from https://www. semanticscholar.org/paper/Abnormal-Returns-to-a-FundamentalAnalysis-Strategy-AbarbanellBushee/3b59ce12e84acfc3a410df16baa9a2f621eb372b

2. Aghion, P., Van Reenen, J., \& Zingales, L. (2013). Innovation and institutional ownership. Retrieved from https://www.aeaweb.org/ articles?id=10.1257/aer.103.1.277

3. Antoniou, A., Guney, Y., \& Paudyal, K. (2008). The Determinants of Capital Structure: Capital MarketOriented versus Bank-Oriented Institutions. The Journal of Financial and Quantitative Analysis, 43(1), 59-92. Retrieved from http:// www.jstor.org/stable/27647340

4. Arellano, M., \& Bond, S. (1991). Some Tests of Specification for Panel Data: Monte Carlo Evidence and an Application to Employment Equations. The Review of Economic Studies, 58(2), 277-297. https://doi. org/10.2307/2297968

5. Arellano, M., \& Bover, O. (1995). Another look at the instrumental variable estimation of errorcomponents models. Journal of Econometrics, 68(1), 29-51. https://doi.org/10.1016/03044076(94)01642-D

6. Bagnoli, M., Clement, M. B., \& Watts, S. G. (2005). Around-theclock media coverage and the timing of earnings announcements. Retrieved from https://papers.ssrn. com/sol3/papers.cfm?abstract_ id $=570247$

7. Barber, B., \& Odean, T. (2008, April). All that Glitters: The Effect of Attention and News. The Review of Financial Studies, 21(2), 785818, https://doi.org/10.1093/rfs/ hhm079

8. Baum, C. F., Barkoulas, J. T., \& Caglayan, M. (2001). Nonlinear adjustment to purchasing power parity in the post-Bretton Woods era. Journal of International Money and Finance, 20(3), 379-399. https://doi.org/10.1016/S02615606(00)00043-7

9. Benlemlih, M., \& Bitar, M. (2018). Corporate Social Responsibility and Investment Efficiency. Journal of Business Ethics, 148(3), 647-671. https://doi.org/10.1007/s10551016-3020-2

10. Bertrand, M., \& Mullainathan, S. (2003). Enjoying the quiet life? Corporate governance and managerial preferences, 111(5), 1043-1075.

11. Bharath, S. T., Jayaraman, S., \& Nagar, V. (2013). Exit as Governance: An Empirical Analysis. The Journal of Finance, 68(6), 2515-2547. https://doi. org/10.1111/jofi.12073

12. Bhikha, V. (2014). Corporate Governance in South Africa: The Role of Institutional Investors (Master of Financial Management). University of Cape Town.

13. Biddle, G. C., Hilary, G., \& Verdi, R. S. (2009). How does financial reporting quality relate to investment efficiency? Journal of Accounting and Economics, 48(2), 112-131. https://doi.org/10.1016/j. jacceco.2009.09.001

14. Blume, M. E., \& Keim, D. B. (2012). Institutional investors and stock market liquidity: trends and relationships (August 21, 2012). Jacobs Levy Equity Management Center for Quantitative Financial Research Paper. http://dx.doi. org/10.2139/ssrn.2147757

15. Blundell, R., \& Bond, S. (1998). Initial conditions and moment restrictions in dynamic panel data models. Journal of Econometrics, 87(1), 115-143. https://doi.org/10.1016/S03044076(98)00009-8

16. Boone, A. L., \& White, J. T. (2015). The effect of institutional ownership on firm transparency and information production. Journal of Financial Economics, 117(3), 508-533. https://doi. org/10.1016/j.jfineco.2015.05.008

17. Cai, J., \& Zhang, Z. (2011). Leverage change, debt overhang, and stock prices. Journal of Corporate Finance, 17(3), 391-402. https://doi.org/10.1016/j.jcorpfin. 2010.12 .003

18. Chen, R., El Ghoul, S., Guedhami, O., \& Wang, H. (2017). Do state and foreign ownership affect investment efficiency? Evidence from privatizations. Journal of Corporate Finance, 42, 408-421. https://doi.org/10.1016/j.jcorpfin.2014.09.001 
19. Cheung, A., Hasan, M. M., \& Khoo, J. (2021). Distracted institutional shareholders and corporate cash holdings. International Review of Economics \& Finance, 71, 453-466. https://doi. org/10.1016/j.iref.2020.08.018

20. Chordia, T. (2000). Trading Volume and CrossAutocorrelations in Stock Returns. The Journal of Finance (New York), 55(2), 913-935. https://doi. org/10.1111/0022-1082.00231

21. Dellavigna, S., \& Pollet, J. M. (2009). Investor Inattention and Friday Earnings Announcements. The Journal of Finance, 64(2), 709-749. https://doi.org/10.1111/ j.1540-6261.2009.01447.x

22. Edmans, A., \& Holderness, C. G. (2017). Chapter 8 - Blockholders: A Survey of Theory and Evidence. In B. E. Hermalin \& M. S. Weisbach (Eds.), The Handbook of the Economics of Corporate Governance (Vol. 1, pp. 541-636). North-Holland.

23. Edmans, A., \& Manso, G. (2010). Governance Through Trading and Intervention: A Theory of Multiple Blockholders. The Review of Financial Studies, 24(7), 2395-2428. https://doi.org/10.1093/rfs/hhq145

24. Engelberg, J., \& Gao, P. (2011). In search of attention (pp. 1461-1499). https://doi.org/10.1111/j.15406261.2011.01679.x

25. Francis, J., Pagach, D., \& Stephan, J. (1992). The stock market response to earnings announcements released during trading versus nontrading periods. Journal of Accounting Research, 30(2), 165184. Retrieved from www.jstor.org/ stable/2491122 (accessed on June 23, 2021).

26. Gao, R., \& Yu, X. (2020). How to measure capital investment efficiency: a literature synthesis. Accounting \& Finance, 60(1), 299-334. https://doi.org/10.1111/ acfi. 12343

27. Garel, A., Martin-Flores, J., PetitRomec, A., \& Scott, A. (2018). Distracted Investors and Earnings Management. Journal of Corporate Finance, 66, 101801. https://doi. org/10.1016/j.jcorpfin.2020.101801
28. Gervais, S., Kaniel, R., \& Mingelgrin, D. H. (2001). The HighVolume Return Premium. The Journal of Finance, 56(3), 877-919. https://doi.org/10.1111/00221082.00349

29. Gompers, P. A., \& Metrick, A. (2001). Institutional Investors and Equity Prices. The Quarterly Journal of Economics, 116(1), 229-259. https://doi. org/10.1162/003355301556392

30. Harber, M. (2017). The role of institutional investors in promoting long-term value creation: A South African perspective. African Review of Economics and Finance, 9(1), 272291. Retrieved from https://www. ajol.info/index.php/aref/article/ view/162152

31. Hayashi, F. (1982). Tobin's Marginal q and Average q: A Neoclassical Interpretation. Econometrica, 50(1), 213-224. https://doi.org/10.2307/1912538

32. Hirshleifer, D., Lim, S. S., \& Teoh, S. H. (2009). Driven to Distraction Extraneous Events and Underreaction to Earnings News. The Journal of Finance, 64(5), 22892325. https://doi.org/10.1111/ j.1540-6261.2009.01501.x

33. Hirst, D. E., \& Hopkins, P. E. (1998). Comprehensive Income Reporting and Analysts' Valuation Judgments. Journal of Accounting Research, 36, 47-75. https://doi. org/10.2307/2491306

34. Hou, K., Xiong, W., \& Peng, L. (2009). A tale of two anomalies: The implications of investor attention for price and earnings momentum (January 16, 2009). Retrieved from https://ssrn.com/ abstract=976394 or http://dx.doi. org/10.2139/ssrn.976394

35. Hubbard, R. G. (1997). CapitalMarket Imperfections and Investment (National Bureau of Economic Research Working Paper Series, No. 5996). https://doi. org/10.3386/w5996

36. Imegi, J. C., \& Nwokoye, G. A. (2015) The Effectiveness of capital budgeting techniques in evaluating projects' profitability. African Research Review, 9, 166-188.
Retrived from https://www.ajol. info/index.php/afrrev/article/ view/118872

37. Intractive. (2017). $80 \%$ of equity market cap held by institutions. Pension \& Investment. Retrieved from https://www. pionline.com/article/20170425/ INTERACTIVE/170429926/80of-equity-market-cap-held-byinstitutions

38. IoDSA, K. I. (2016). The King IV Report: The Institute of Directors in Southern Africa. Retrieved from http://www.iodsa.co.za/290

39. IRRC. (2011). The State of Engagement Between US Corporations and Shareholders. Retrieved from www.irrcinstitute. org

40. Jabeen, M., \& Ali, S. (2017). Institutional Investors as Monitors of Corporate Managers: A Case Study of Pakistan's Cement Industry and Food and Personal Care Products' Industry. FWU Journal of Social Sciences, 11(2), 109-126. Retrieved from http:// search.ebscohost.com/login. aspx?direct=true \&AuthType=ip,s hib\&db=a9h\&AN=127635306\&s ite $=$ ehost-live\&scope $=$ site\&custid =s5210036

41. Jensen, M. C., \& Meckling, W H. (1976). Theory of the firm: Managerial behavior, agency costs and ownership structure. Journal of Financial Economics, 3(4), 305360. https://doi.org/10.1016/0304405X(76)90026-X

42. Kempf, E., Manconi, A., \& Spalt, O. (2017). Distracted Shareholders and Corporate Actions. Review of Financial Studies, 30(5), 16601695. https://doi.org/10.1093/rfs/ hhw082

43. Koh, P.-S. J. T. B. A. R. (2003). On the association between institutional ownership and aggressive corporate earnings management in Australia. The British Accounting Review, 35(2), 105-128. https://doi.org/10.1016/ S0890-8389(03)00014-3

44. Liu, C., Low, A., Masulis, R. W., \& Zhang, L. (2020, October). Monitoring the monitor: Distracted institutional investors 
and board governance. The Review of Financial Studies, 33(10), 44894531 https://doi.org/10.1093/rfs/ hhaa014

45. Modigliani, F., \& Miller, M. H. (1958). The Cost of Capital, Corporation Finance and the Theory of Investment. The American Economic Review, 48(3), 261-297. Retrieved from http:// www.jstor.org/stable/1809766

46. Nhlapo, N., \& Gumata, N. (2011). Non-bank institutional investment behaviour in the South African market. International Statistical Institute: Proc. 58th World Statistical Congress, 2011, Dublin (Session STS061). Retrieved from https://2011.isiproceedings.org/

47. Ohlson, J. A. (1995). Earnings, Book Values, and Dividends in Equity Valuation. Contemporary Accounting Research, 11(2), 661-687. https://doi. org/10.1111/j.1911-3846.1995. tb00461.x

48. Oyedokun, D. T., Folly, K. A., \& Chowdhury, S. P. (2009, September 23-25). Effect of converter DC fault on the transient stability of a MultiMachine Power System with HVDC transmission lines. Paper presented at the AFRICON 2009.

49. Porter, M. E. (1992). Capital disadvantage: America’s failing capital investment system. Harvard Business Review, 70(5), 65-82. Retrieved from http://europepmc. org/abstract/MED/10121317

50. Refinitiv. (2019). South Africa’s fund industry gets net inflows of $\$ 10$ billion for the first nine months of 2019, despite a volatile market. FANEWS. Retrieved from https://www.fanews.co.za/article/ investments/8/general/1133/ south-africa-s-fund-industrygets-net-inflows-of-10-billionfor-the-first-nine-months-of2019-despite-a-volatile-market/27922\#: :text=Assets\%20under\%20management $\% 20$ in $\% 20$ the,in $\% 202019 \% 20$ year\%20to\%20 date

51. Richardson, S. (2006). Overinvestment of free cash flow. Review of Accounting Studies, 11(2), 159-189. https://doi.org/10.1007/ s11142-006-9012-1
52. Roodman, D. (2009). How to do Xtabond2: An Introduction to Difference and System GMM in Stata. The Stata Journal, 9(1), 86-136. https://doi. org/10.1177/1536867x0900900106

53. Segerstrom, S. (2020). Institutional Ownership in the UK. Insights. Retrieved from https://insight.factset.com/institutional-ownershipin-the-uk\#: :text=Institutional $\% 20$ ownership\%20in\%20the $\% 20$ FTSE,three\%20of\%20these $\% 20$ being\%20international

54. Shleifer, A., \& Vishny, R. W. (1997). A Survey of Corporate Governance. The Journal of Finance, 52(2), 737-783. https:// doi.org/10.1111/j.1540-6261.1997. tb04820.x

55. Sibanda, M., \& Holden, M. (2014). Institutional Investors And The Finance-Growth Nexus: Evidence From South Africa. Applied Business Research, 30(1), 149.

56. Stein, J. C. (2003). Chapter 2 - Agency, Information and Corporate Investment. In G. M. Constantinides, M. Harris, \& R. M. Stulz (Eds.). Handbook of the Economics of Finance, 1, 111-165.

57. Stein, L. C., \& Zhao, H. (2016). Distracted Directors. Retrieved from https://wpcarey.asu.edu/sites/ default/files/workingpaper1hongzhaolukesteinasu.pdf

58. Stoughton, N. M., Wong, K. P., \& Yi, L. (2017). Investment Efficiency and Product Market Competition. Journal of Financial and Quantitative Analysis, 52(6), 26112642. https://doi.org/10.1017/ S0022109017000746

59. Survé, Y. (2009). The effect of institutional shareholders on the level and mix of South African chief executive officers' compensation. Retrieved from https://core.ac.uk/ download/pdf/39666383.pdf

60. Teoh, S. H., \& Wong, T. J. (2015). Why New Issues and HighAccrual Firms Underperform: The Role of Analysts' Credulity. The Review of Financial Studies, 15(3), 869-900. https://doi.org/10.1093/ rfs/15.3.869

61. Thomas, L. (2017). Ownership of JSE-Listed Companies: Research
Report for National Treasury. Retrieved from https://scholar. google.com/scholar?hl=en\&as_sdt $=0 \% 2 \mathrm{C} 5 \& \mathrm{q}=60 . \% 09$ Thomas $\% 2 \mathrm{C}+$ L.+\%282017\%29.+Ownership+of+ JSE-Listed+Companies\%3A+Rese arch+Report+for+National+Treas ury.\&btnG=

62. Titman, S., Wei, K. C. J., \& Xie, F. (2004). Capital Investments and Stock Returns. Journal of Financial and Quantitative Analysis, 39(4), 677-700. https://doi.org/10.1017/ S0022109000003173

63. Vengesai, E. (2019). Country risk components and firm investment behaviour of JSE listed firms. Retrieved from https:// www.zbw.eu/econis-archiv/bitstream/11159/4325/1/1694182908. pdf

64. Wang, X. (2017). Investor Attention Strategy. Journal of Behavioral Finance, 18(4), 390-399. https://doi.org/10.1080/15427560. 2017.1344674

65. Ward, C., Yin, C., \& Zeng, Y. (2017). Motivated Institutional Investors and Firm Investment Efficiency. Retrieved from https://www.efmaefm. org/OEFMAMEETINGS/ EFMA\%20ANNUAL\%20 MEETINGS/2017-Athens/papers/ EFMA2017_0226_fullpaper.pdf

66. Windmeijer, F. (2005). A finite sample correction for the variance of linear efficient two-step GMM estimators. Journal of Econometrics, 126(1), 25-51. https://doi. org/10.1016/j.jeconom.2004.02.005

67. Yin, C. (2018). Institutional Investors: their incentives for monitoring companies and the effect on corporate governance (Ph.D. thesis). University of Reading.

68. Zhang, Q. (2016). Corporate governance, institutional investors and firm performance: A comparative study of South Africa and China (Ph.D. thesis). University of Stellenbosch. 


\section{APPENDIX A}

\begin{tabular}{|c|c|c|}
\hline Variable & Description & Source \\
\hline $\begin{array}{l}\text { Distraction } \\
\text { Measure Variable }\end{array}$ & 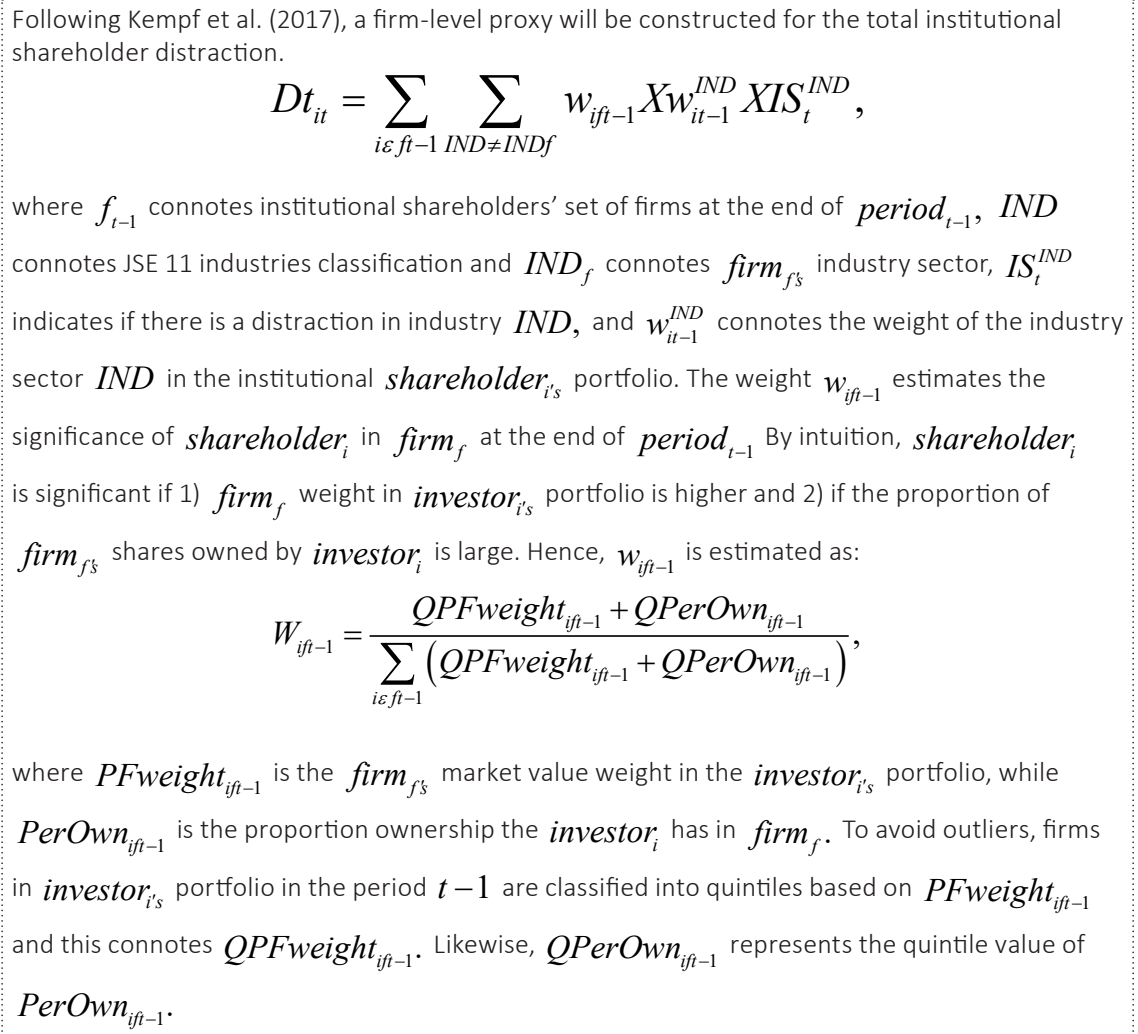 & S\&P Capital IQ. \\
\hline \multicolumn{3}{|c|}{ Investment Regression Variables } \\
\hline AT & Total Assets & S\&P Capital IQ \\
\hline | Total & $\begin{array}{l}\text { Annual total investment expenditure normalized by AT: [Capital expenditure (CAPX) + acquisition } \\
\text { expenditure (AQC) + R\&D expenditure (XRD) - Receipts from sale of property, plant and } \\
\text { equipment(SPPE)] / AT (Richardson, 2006; Ward et al., 2017) }\end{array}$ & S\&P Capital IQ \\
\hline I Maintenance & $\begin{array}{l}\text { Annual required investment expenditure to maintain assets in place normalized by AT: } \\
\text { Depreciation and amortization (DPC)/AT (Richardson, 2006; Ward et al., 2017) }\end{array}$ & S\&P Capital IQ \\
\hline I New & $\begin{array}{l}\text { Annual investment expenditure on new projects normalized by AT: ITotal- I Maintenance } \\
\text { (Richardson, 2006; Ward et al., 2017) }\end{array}$ & S\&P Capital IQ \\
\hline MV & Market value of equity: price(PRCC F) * common shares outstanding (CSHO) (Ward et al., 2017) & S\&P Capital IQ \\
\hline V/P & $\begin{array}{l}\text { Growth opportunity: Assets in place/MV, where assets in place are estimated as } \\
(1-\alpha r) B V+\alpha(1+r) X-\alpha r d, \alpha=w / 1+r-w, r=12 \%, w=0.62, B V \text { is the book } \\
\text { value of equity(CEQ), d is annual dividend (DVC), and } \mathrm{X} \text { is operating income after depreciation } \\
\text { (OIADP) (Richardson, 2006; Ward et al., 2017) }\end{array}$ & S\&P Capital IQ. \\
\hline Leverage & $\begin{array}{l}\text { Leverage ratio: the book value of total debt (long term debt(DLTT) + short-term debt(DLC)) } \\
\text { divided by the sum of the book value of total debt and Book value of Equity (Richardson, 2006; } \\
\text { Ward et al., 2017) }\end{array}$ & S\&P Capital IQ. \\
\hline Cash & $\begin{array}{l}\text { Cash holding ratio: Cash and short-term investment(CHE) divided by AT at the start of year } \\
\text { (Richardson, 2006; Ward et al., 2017) }\end{array}$ & S\&P Capital IQ. \\
\hline Age & $\begin{array}{l}\text { Firm age: the natural log of ( } 1+\text { the number of years the fi } \\
\text { rm has been listed on JSE as of the start of the year) (Richardson, 2006; Ward et al., 2017) }\end{array}$ & S\&P Capital IQ. \\
\hline Size & The natural log of AT at the start of the year (Richardson, 2006; Ward et al., 2017) & S\&P Capital IQ. \\
\hline Return & $\begin{array}{l}\text { The per cent change of } \\
\text { market value over that prior year: } M V_{t} / M V_{t-1} \text { (Richardson, 2006; Ward et al., 2017) }\end{array}$ & S\&P Capital IQ \\
\hline MTB & $\begin{array}{l}\text { Market-to-book ratio: the market value of asset (MV +Total debt) divided by AT (Stoughton et al., } \\
\text { 2017; Ward et al., 2017) }\end{array}$ & S\&P Capital IQ. \\
\hline Tangibility & $\begin{array}{l}\text { Firm asset tangibility: Property Plant and Equipment(PPENT)/AT (Stoughton et al., 2017; Ward et } \\
\text { al., 2017) }\end{array}$ & S\&P Capital IQ \\
\hline Inefinvest & $\begin{array}{l}\text { Inefficient investment proxy variable: residual of the investment regression (Richardson, 2006; } \\
\text { Stoughton et al., 2017) }\end{array}$ & S\&P Capital IQ. \\
\hline
\end{tabular}

